\title{
Analysis of impacts from environmental factors evaluated by icf in individuals post-cva
}

\author{
Análise dos impactos de fatores ambientais \\ avaliados pela cif em indivíduos pós-avc
}

Kátia Suely Queiroz Silva Ribeiro, Robson da Fonseca Neves, Geraldo Eduardo Guedes de Brito, Ingrid Davis da Silva Gadelha, Ed'Cleberson Alves de Morais, Vitor Hugo de Oliveira Nascimento *

Universidade Federal da Paraíba (UFPB), João Pessoa, PB, Brazil

\begin{abstract}
Introduction: The CVA is the second cause of death in Brazil, presenting with serious clinical repercussions and as a public health issue. Live with the disabilities caused by it requires facing daily situations, which can increase the disability, such as the ones imposed by the environment inside or outside home. Objective: Analyze the environmental factors of ICF with a facilitator or barrier for victims of Stroke. Materials and methods: A cross-sectional study, 152 individuals; span of less than 60 months involvement and enrolled in the Family Health Units in João Pessoa, Brazil. A questionnaire was used to characterize the socio-economic and clinical form and the Core Set for stroke to identify environmental factors. The data were stored in Epilnfo 7. Associations between environmental factors and the variables age, gender, and marital status verified by chi-square test. Results: Assistive technologies and products or substances for personal consumption were the main factors recognized as facilitators, followed by interpersonal relationships. The most prevalent factors as barriers were the physical structures of public and private spaces, highlighting the physical geography of their residence. It was found that the immediate family was associated with variable
\end{abstract}

* KSQSR: PhD, e-mail: katiaqsribeiro@yahoo.com.br RFN: MSc, e-mail: robsonfisioba@gmail.com GEGB: Grad, e-mail: eduardo.guedes.ufpb@gmail.com IDSG: MSc, e-mail: ingridgadelha_@hotmail.com ECAM: Grad, e-mail: clebinhoalves@hotmail.com VHON: Grad, e-mail: vitorugo_992@hotmail.com 
marital status, use of products and technology for personal use in daily life was associated with age and, friends partnered with variable gender. Conclusions: The Core Set is shown as a sensitive instrument to capture the barriers and facilitators in population surveys. Their findings point to the need to think about public policy more appropriate for this population.

Keywords: Stroke. Cross-Sectional Studies. International Classification of Functioning. Disability and Health. Rehabilitation.

\section{Resumo}

Introdução: O AVC é a segunda causa de morte no Brasil apresentando repercussões clínicas graves e como uma questão de saúde pública. Viver com a deficiência causada exige enfrentamento de situações cotidianas que podem aumentar a deficiência, como as impostas pelo ambiente dentro ou fora de casa. Objetivo: Analisar os fatores ambientais da CIF com um facilitador ou uma barreira para as vítimas de AVC. Materiais e métodos: Estudo transversal, envolvendo 152 indivíduos com tempo de acometimento menor que 60 meses e vinculados as Unidades de Saúde da Família em João Pessoa/PB. Um questionário estruturado foi utilizado para caracterizar a amostra e o core set da CIF para identificar os fatores ambientais. Os dados foram armazenados no programa Epi Info 7. Associações entre fatores ambientais e as variáveis idade, sexo e estado civil foram verificadas pelo teste do qui-quadrado. Resultados: Tecnologias de apoio e produtos ou substâncias para consumo pessoal foram os principais fatores como facilitadores, seguidos pela família imediata. As barreiras mais prevalentes foram: estruturas físicas dos espaços públicos e privados, destacando a geografia física da sua residência. A família imediata associou-se a variável estado civil; o uso de produtos e tecnologia para uso pessoal na vida diária com a idade e, amigos com a variável sexo. Conclusões: $O$ core set se mostrou um instrumento sensivel para captar as barreiras e facilitadores em inquéritos com sujeitos pós-AVC. Seus resultados apontam para a necessidade de se pensar em políticas públicas mais adequadas para esta população.

Palavras-chave: Acidente Vascular Cerebral. Estudos Transversais. Classificação Internacional de Funcionalidade. Incapacidade e Saúde. Reabilitação.

\section{Introduction}

The high number of people with disabilities in Brazil, according to a 2010 Demographic census from the Brazilian Institute of Geography and Statistics (IBGE, 2011), 24.5 million people had some type of disability, almost $24 \%$ of the Brazilian population. These numbers demonstrate the need for assessment measures, which act as interventions in disadvantages and incapacities resulting from disabilities, and provide inclusion in social, economic and politic life, bearing in mind that just $5 \%$ of these individuals are in the labor market (1).

In this context, the National Policy for health of Persons with Disabilities (2) has represented a real step forward in recognition of disability in Brazil. It has also been gaining notoriety by providing to this population segment a range of friendly environments for health, adequate attention to their needs, as well as the incentive for healthy habits and lifestyles that contribute to quality of life, functional capacity and human performance.
The main causes of disability in Brazil are results of congenital and perinatal disorders, communicable diseases, psychiatric disorders, alcohol and drugs abuse, malnutrition, as well as traffic accidents and other forms of violence (2). In the last decades, studies have shown that the causes of disability are also associated with chronic non-communicable diseases that increase with this life expectancy of the Brazilian population (3-5).

Among the chronic non-communicable diseases, the cerebrovascular diseases are the third leading cause of death in Brazil, with a prevalence of 5.8 cases per thousand inhabitants over 25 years old, meaning approximately one hundred thousand annual deaths (2). Among cerebrovascular diseases, the cerebrovascular accident (CVA) was responsible for 426,679 hospitalizations between 2003 and 2006 in Brazil (2). CVAs contribute to high mortality rates and interfere directly in the life quality of patients who have had one (6).

The CVA is characterized by an acute emergence of neurological dysfunction, due to an abnormality in cerebral circulation, resulting in signs and symptoms 
that correspond to commitment of focal areas of the brain. It is a sudden event with temporary or permanent neurological deficits of several intensities $(7,8)$.

Currently, CVA is the third leading cause of death worldwide and the second in Brazil, presenting itself as an infirmity with serious clinical repercussions and as a serious public health issue (2). In 2003, in the Northeast region of Brazil, the mortality rate caused by CVA was estimated at 54.6 per one hundred thousand inhabitants (9). The hospitalization rate by Brazilian Unified Health System (SUS) in 2009 by stroke was equal to $8.39 \%$ of Brazilian population. Nevertheless, the rate of the state of Paraíba and its capital was even higher, representing $10.53 \%$ and $10.62 \%$, respectively (10).

The study done by Amaral et al., in 2012, stated that the number of people with disabilities or permanent restrictions of mobility in the city of João Pessoa, deserves attention, due to the vast number of people suffering from CVA consequences (14\%) (11). The most affected functions of the body are the neuromusculoskeletal and the ones related to movement. Beyond these damages, it is important to point to some other disorders, such as in behavior, language, sensibility, visual and swallowing, which can lead to the need for assistance of other people to perform their own basic daily activities, such as hygiene, locomotion and eating $(12,13)$.

To live with disabilities caused by CVA requires facing daily situations, which can increase the disability, such as the ones imposed by the environment inside or outside home. That is the reason why it is necessary to know the relationship between disabilities and environment, keeping in mind that factors related to the environment can restrict or facilitate the patients' abilities in execution of day-to-day activities inside their social and cultural context.

To this end, the International Classification of Functioning, Disability and Health (ICF), approved by the World Health Organization (WHO), in 2001, appears as an important tool to describe life conditions and promote policies aiming for social inclusion. The focus proposed by ICF reflects the transition from an approach focused on disease consequences, to one which prioritizes the functioning as a health component, considering the environment as a facilitator or as a barrier to the performance of actions and tasks (14).

According to ICF, the environmental factors constitute the physical, social and attitudinal environments where people live and conduct their lives. These factors include: products and technologies for personal consumption, personal usage in everyday life and communication; products and technologies used in projects, architecture, and public or private building construction; physical geography; immediate and extended families; health professionals; friends; acquaintances, patterns and community members (15).

Different environments can have distinct impacts on the same person with a particular health condition. An environment with barriers, or without facilitators, limits individual performance. On the other hand, an environment equipped with facilitators provides the capabilities to perform habitual actions in a social context $(15,16)$.

Analysis of functioning, as well as a clinical diagnosis of CVA, can provide information to health management and planning that is attentive to service needs, hospitalization time and care levels, creates better health conditions and greater involvement in social life. This analysis, conducted in accordance with ICF, can be utilized as a statistical, investigational, clinical, social policy and pedagogical tool (15), which is of great interest to the rehabilitation and public health fields. In addition, it can support research and evaluation in the quality of services in rehabilitation (17), promoting better health conditions and quality of life.

Facing these challenges, the aim of this study is to describe and analyze the environmental factors of ICF, which can both act as facilitators or barriers in patients after CVA, and as associate them with sociodemographic profiles.

\section{Materials and methods}

This is a quantitative, observational cross-sectional study, with a sample of 152 individuals diagnosed with CVA in the last 60 months. All of the male and female subjects were above 18 years old and belonged to the area each Family Health Team (FHT, a strategy to organize primary health care adopted by the Brazilian Ministry of Health since 1996) is responsible to for care in the five Health Districts (HD) of João Pessoa.

The population under study was set up from lists provided by the Municipal Department of Health, which had 324 individuals who had suffered CVA between 2006 and 2010 and were attached to Family Health Teams. Based on this list, the sample was calculated from the formula: $\mathrm{n}=\mathrm{Z} 2 \mathrm{PQ} / \mathrm{d} 2$, where 
$\mathrm{n}=$ minimum sample size; $\mathrm{Z}=$ reduced variable; $\mathrm{P}=$ probability to find the studied phenomenon; $\mathrm{Q}=$ $1-\mathrm{P} ; \mathrm{d}=$ desired precision. It was adopted that $\mathrm{P}=50 \%$ because it was a multidimensional assessment and the desired precision for the study was $10 \%$. Based on these criteria, the minimum expected sample calculated was 147 individuals.

As an interview tool, a structured questionnaire was utilized containing questions about socio-economic and clinical profiles of the individuals, besides items that evaluate the influence of environmental factors in the functioning of people with CVA, through the ICF's Core Set of CVA. The expression core set refers to essential items to be raised in a specific health condition (18).

Data was collected between August 2010 and November 2011, during visits to participants' homes. In the cases when the individual presented cognitive or speech deficit, data was collected from a caregiver or another proxy informant. Cognitive deficit was evaluated utilizing the Score of Mini-Mental State Examination (SMMSE); literate individuals needed to achieve SMMSE equal or superior to 18 points and illiterate individuals equal or superior to 13 points in SMMSE, to be a participant (19). Exclusion criteria adopted for the study was the presence of serious incapacities before the CVA.

Information collected was systematized in a database and analyzed by the software Epi Info, version 7. Association between environment factors and the variables: age-group, gender and marital status, was verified by means of Chi-Square test with a significance level of 5\%.

This research obeyed ethical standards of resolution $n^{\circ}$ 196/96, from the Brazilian National Health Council, which prioritizes human rights for individuals undergoing experiences in health research. This study was submitted to the Ethics Committee in Research from the University Hospital Lauro Wanderley (UHLW) and has been approved with the protocol number 430/09.

\section{Results}

Table 1 shows the gender distribution of the sample: $52.0 \%$ women and $48.0 \%$ men. There's a greater concentration of people in higher agegroups; $71.0 \%$ were 60 years or older and $28.9 \%$ were 25 to 59 years old; though the number of individuals corresponding to the age-group from 25 to 59 years old is considered high. Most of the volunteers or their caregivers did not know the type of CVA $(44.7 \%) ; 40.8 \%$ of interviewees had ischemic CVA and $14.5 \%$ hemorrhagic. More than half of interviewees (65.1\%) were married; the others $(34.9 \%)$ were widowed, single or divorced. At the interview moment, $70.4 \%$ of the individuals had had one CVA for at least over a year. Time of involvement is referent to the last CVA episode, as $35.5 \%$ of interviewees had had two or more episodes.

According to table 2, the main factors that would serve as either barriers or facilitators identified by the interviewees were assistive technologies (products and technology for communication and products and technology for personal usage in daily life) and the products or substances for personal consumption, followed by interpersonal relationships (immediate family; health professionals; friends; acquaintances, companions, colleagues, neighbors and community members; extended family). The most prevalent factors as barriers were related to physical structures in public and private spaces (products and technology used in projects, architecture and construction of private buildings; and physical geography). $48.2 \%$ of interviewees emphasized conditions of the physical geography of their residences as a barrier.

All the factors from this study had significant prevalence as facilitators; these are presented in tables 3,4 and 5 .

Immediate family was reported as a facilitator significantly more by married individuals than by non-married individuals $(p=0.000)$, highlighted among other factors $(74.5 \%)$. The use of Products and technologies for personal usage in daily life was reported as facilitator variable significantly more $(p=0.012)$ by individuals aged 60 or over, than individuals aged 25 to 59 . The Acquaintances, companions, colleagues, neighbors and community members was reported as a facilitator variable significantly more $(p=0.05)$ by females than by males. Friends was reported as a facilitator variable significantly more by women ( $p=0.016)$ than by men.

The other environmental factors did not show significant difference amongst the marriage and gender variables. 
Table 1 - Characteristics of the sample - João Pessoa - Brazil - 2011

\begin{tabular}{|c|c|c|c|}
\hline Characteristics & $\mathrm{n}$ & $\%$ & IC \\
\hline \multicolumn{4}{|l|}{ Gender } \\
\hline Female & 79 & 52.0 & $43.73-60.14$ \\
\hline Male & 73 & 48.0 & $39.86-56.27$ \\
\hline \multicolumn{4}{|l|}{ Age-group (years) } \\
\hline 60 years or older & 108 & 71.0 & $63.15-78.11$ \\
\hline 25-59 years old & 44 & 28.9 & $21.89-36.85$ \\
\hline \multicolumn{4}{|l|}{ Type of CVA } \\
\hline Did not know to inform & 68 & 44.7 & $36.68-53.01$ \\
\hline Ischemic & 62 & 40.8 & $32.90-49.05$ \\
\hline Hemorrhagic & 22 & 14.5 & $9.30-21.09$ \\
\hline \multicolumn{4}{|l|}{ Marital status } \\
\hline Married/ Living together & 99 & 65.1 & $56.99-72.67$ \\
\hline Widowed & 29 & 19.1 & $13.17-26.24$ \\
\hline Separated & 13 & 8.6 & $4.63-14.18$ \\
\hline Single & 11 & 7.2 & $3.67-12.58$ \\
\hline \multicolumn{4}{|l|}{ Time of involvement (months) } \\
\hline 13 months or more & 107 & 70.4 & $62.46-77.52$ \\
\hline Up to 12 months & 45 & 26.6 & $22.48-37.54$ \\
\hline \multicolumn{4}{|l|}{$\begin{array}{l}\text { Number of involvements } \\
\text { in the last } 5 \text { years }\end{array}$} \\
\hline 1 & 98 & 64.6 & $56.31-72.06$ \\
\hline 2 or more & 54 & 35.5 & 27.94-43.69 \\
\hline
\end{tabular}

Source: Research data.

Note: $\mathrm{n}=$ sample number; $(\%)$ = frequency; IC = Confidence interval $95 \%$

Table 2 - Recognition of facilitator or barriers factors by people who had suffered CVA - João Pessoa - 2011

\begin{tabular}{|c|c|c|c|c|c|}
\hline \multirow[t]{2}{*}{ Environmental factors } & \multicolumn{2}{|c|}{ Facilitatior } & \multicolumn{2}{|c|}{ Barrier } & \multirow[t]{2}{*}{$\mathrm{N}$ total $(\mathrm{N}=152)$} \\
\hline & $\mathbf{n}$ & $\%$ & $\mathbf{n}$ & $\%$ & \\
\hline $\begin{array}{l}\text { Products and Technologies for } \\
\text { communication }\end{array}$ & 67 & 95.7 & 3 & 4.3 & 70 \\
\hline $\begin{array}{l}\text { Products and Technologies } \\
\text { for personal usage in daily life }\end{array}$ & 69 & 92.0 & 6 & 8.0 & 75 \\
\hline $\begin{array}{l}\text { Products or substances for } \\
\text { personal consumption }\end{array}$ & 130 & 90.3 & 14 & 9.7 & 144 \\
\hline Immediate family & 123 & 89.8 & 14 & 10.2 & 137 \\
\hline Health professionals & 131 & 88.5 & 17 & 14.5 & 148 \\
\hline Friends & 91 & 83.5 & 18 & 16.5 & 109 \\
\hline $\begin{array}{l}\text { Acquaintances, companions, } \\
\text { colleagues, neighbors and community } \\
\text { members }\end{array}$ & 83 & 82.2 & 18 & 17.8 & 101 \\
\hline Extended family & 71 & 77.2 & 21 & 22.8 & 92 \\
\hline $\begin{array}{l}\text { Products and technology } \\
\text { used in projects, } \\
\text { architecture and } \\
\text { construction of public buildings }\end{array}$ & 98 & 73.7 & 35 & 26.3 & 133 \\
\hline
\end{tabular}


Table 2 - Recognition of facilitator or barriers factors by people who had suffered CVA - João Pessoa - 2011

\begin{tabular}{|c|c|c|c|c|c|}
\hline Environmental factors & \multicolumn{2}{|c|}{ Facilitatior } & \multicolumn{2}{|c|}{ Barrier } & $\mathrm{N}$ total $(\mathrm{N}=152)$ \\
\hline $\begin{array}{l}\text { Products and technology } \\
\text { used in projects, } \\
\text { architecture and construction of private } \\
\text { buildings }\end{array}$ & 97 & 72.9 & 36 & 27.1 & 133 \\
\hline Physical geography & 73 & 51.8 & 68 & 48.2 & 141 \\
\hline
\end{tabular}

Source: Research data.

Note: $\mathrm{n}$ = sample number; $(\%)$ = frequency; $\mathrm{N}$ total= Total subjects who declared facilitator or barrier

Table 3 - Association between environmental factors and the marital status variable - João Pessoa - 2011

\begin{tabular}{|c|c|c|c|c|c|}
\hline \multirow[t]{3}{*}{ Environmental factors } & \multicolumn{4}{|c|}{ Marital status } & \multirow[t]{3}{*}{$\mathrm{p}$} \\
\hline & \multicolumn{2}{|c|}{ Married } & \multicolumn{2}{|c|}{ Others } & \\
\hline & $\mathrm{n}$ & $\%$ & $\mathrm{n}$ & $\%$ & \\
\hline \multicolumn{6}{|l|}{ Immediate family } \\
\hline Facilitatior & 88 & 97.8 & 35 & 74.5 & \multirow{2}{*}{ * 0.000} \\
\hline Barriers & 2 & 2.2 & 12 & 25.5 & \\
\hline \multicolumn{6}{|l|}{$\begin{array}{l}\text { Products and technology } \\
\text { used in daily life }\end{array}$} \\
\hline Facilitatior & 45 & 91.8 & 24 & 92.3 & \multirow{2}{*}{1.000} \\
\hline Barriers & 4 & 8.2 & 2 & 7.7 & \\
\hline \multicolumn{6}{|l|}{ Friends } \\
\hline Facilitatior & 60 & 82.2 & 31 & 86.6 & \multirow{2}{*}{0.604} \\
\hline Barriers & 13 & 17.8 & 5 & 13.9 & \\
\hline \multicolumn{6}{|l|}{$\begin{array}{l}\text { Acquaintances, companions, } \\
\text { colleagues, neighbors } \\
\text { and community members }\end{array}$} \\
\hline Facilitation & 55 & 83.3 & 28 & 80.0 & \multirow{2}{*}{0.677} \\
\hline Barriers & 11 & 16.7 & 7 & 20.0 & \\
\hline
\end{tabular}

Source: Research data.

Note: Others $=$ Widowed, separated and single; $\mathrm{n}=$ sample number; $(\%)=$ frequency; $\mathrm{p}=\mathrm{p}$ - value; ${ }^{*} \mathrm{p}$-value assuming $\mathrm{p}<0.05$

Table 4 - Association between environmental factors and the age-group variable - João Pessoa - 2011

\begin{tabular}{|c|c|c|c|c|c|}
\hline \multirow[t]{3}{*}{ Environmental factors } & \multicolumn{4}{|c|}{ Age - group } & \multirow[t]{3}{*}{$\mathrm{p}$} \\
\hline & \multicolumn{2}{|c|}{$25-59$ years old } & \multicolumn{2}{|c|}{60 or older } & \\
\hline & $\mathrm{n}$ & $\%$ & $\mathrm{n}$ & $\%$ & \\
\hline \multicolumn{6}{|l|}{ Immediate family } \\
\hline Facilitatior & 30 & 88.2 & 81 & 89.0 & \multirow{2}{*}{0.903} \\
\hline Barriers & 4 & 11.8 & 10 & 11.0 & \\
\hline \multicolumn{6}{|l|}{$\begin{array}{l}\text { Products and technology } \\
\text { used in daily life }\end{array}$} \\
\hline Facilitatior & 8 & 72.7 & 55 & 98.2 & \multirow{2}{*}{${ }^{\star} 0.012$} \\
\hline Barriers & 3 & 27.3 & 1 & 1.8 & \\
\hline
\end{tabular}


Table 4 - Association between environmental factors and the age-group variable - João Pessoa - 2011

\begin{tabular}{|c|c|c|c|c|c|}
\hline Environmental factors & \multicolumn{4}{|c|}{ Age - group } & $\mathrm{p}$ \\
\hline Facilitatior & 21 & 72.4 & 59 & 86.8 & \multirow{2}{*}{0.089} \\
\hline Barriers & 8 & 27.6 & 9 & 13.2 & \\
\hline \multicolumn{6}{|l|}{$\begin{array}{l}\text { Acquaintances, companions, } \\
\text { colleagues, neighbors } \\
\text { and community members }\end{array}$} \\
\hline Facilitation & 19 & 70.4 & 55 & 87.3 & \multirow{2}{*}{0.054} \\
\hline Barriers & 8 & 29.6 & 8 & 12.7 & \\
\hline
\end{tabular}

Source: Research data.

Note: $\mathrm{n}=$ sample number; $(\%)=$ frequency; $\mathrm{p}=\mathrm{p}$ - value; ${ }^{\star} \mathrm{p}$-value assuming $\mathrm{p}<0.05$.

Table 5 - Association between environmental factors and the gender variable - João Pessoa - 2011.

\begin{tabular}{|c|c|c|c|c|c|}
\hline \multirow[t]{3}{*}{ Environmental factors } & \multicolumn{4}{|c|}{ Gender } & \multirow[t]{3}{*}{$\mathrm{p}$} \\
\hline & \multicolumn{2}{|c|}{ Male } & \multicolumn{2}{|c|}{ Female } & \\
\hline & $\mathrm{n}$ & $\%$ & $\mathrm{n}$ & $\%$ & \\
\hline \multicolumn{6}{|l|}{ Immediate family } \\
\hline Facilitatior & 54 & 93.1 & 57 & 85.1 & \multirow{2}{*}{0.156} \\
\hline Barriers & 4 & 6.9 & 10 & 14.9 & \\
\hline \multicolumn{6}{|l|}{$\begin{array}{l}\text { Products and technology } \\
\text { used in daily life }\end{array}$} \\
\hline Facilitatior & 34 & 97.1 & 29 & 90.6 & \multirow{2}{*}{0.342} \\
\hline Barriers & 1 & 2.9 & 3 & 9.4 & \\
\hline \multicolumn{6}{|l|}{ Friends } \\
\hline Facilitatior & 31 & 72.1 & 49 & 90.7 & \multirow{2}{*}{ *0.016 } \\
\hline Barriers & 12 & 27.9 & 5 & 9.3 & \\
\hline \multicolumn{6}{|l|}{$\begin{array}{l}\text { Acquaintances, companions, } \\
\text { colleagues, neighbors } \\
\text { and community members }\end{array}$} \\
\hline Facilitation & 28 & 73.7 & 46 & 88.5 & \multirow{2}{*}{0.070} \\
\hline Barriers & 10 & 26.3 & 6 & 11.5 & \\
\hline
\end{tabular}

Source: Research data.

Note: $\mathrm{n}=$ sample number; $(\%)=$ frequency; $\mathrm{p}=\mathrm{p}$ - value; ${ }^{*} \mathrm{p}$-value assuming $\mathrm{p}<0.05$.

\section{Discussion}

This study reveals the fact that people who had suffered CVA pointed out products and technologies were facilitators. Products and technologies are used by these people in everyday life in order to keep vital functions and to relate with other people. From those who had suffered CVA reported interpersonal relationships, with the people who they are relating daily, as facilitators. Evidencing the way how people with CVA perceive tools, products and technologies, and people that assist or lead them, these components can improve their living conditions. Related to barriers, the study makes clear that it is necessary to progress and to improve public spaces for disabled people who had suffered CVA or have other disabilities, from private residence space to commercial buildings and urban spaces where people engage in human activities, including social life. 
The products and technologies for communication are important to individuals who have a certain type of disability, especially those ones resulting from CVA, such as aphasia and cognition alterations, for example. Since these products/technologies facilitate information exchange about health condition between patients and their care providers, they also contribute to physical and social health improvements $(5,20)$. The products and technologies for communication represent equipment, products and technology utilized by people in activities of data transmission and reception, including those adapted or specially designed for, situated on or close to people who utilize them. They include general products and technologies and communication assistance (15). Therefore, these products enable effective communication, influence decision-making and generate positive sensations in disabled individuals seeking more complimentary performance with their needs, as well as open opportunities that enable interaction between them and their caregivers, who are either health professionals or family members (21).

The products and technologies for personal usage in daily life stood out as facilitators, by proportionating benefits for people who had and present mobility deficit. According to ICF, they are equipment, products and technologies used by people in their daily activities, included those adapted or specially designed for, situated on or close to people who utilize them. It is included general products and technologies and general assistance to personal usage (15). Equipment such as canes, crutches, wheelchairs and bath chairs represent a facilitator to locomotion inside or outside the home, ensuring the individual more confidence, safety and social participation (22 - 24). People with disabilities use assistive technologies as a way to compensate function loss or commitment; these devices are capable of assisting in areas related to communication, education, environmental accessibility and occupational and recreational activities, promoting more independence and improving life quality (16). Their usage also promotes growth from a psychosocial aspect, since they help these people to improve their self-esteem and well-being, help the re-learning and execution of daily tasks; the emotional gain by performing these tasks reduces and eliminates frustration about completing other particular tasks $(24,25)$.

WHO identifies Products or substances for personal consumption, listed by ICF as natural or artificial substance, harvested, processed or manufactured to be ingested as raw food, processed or prepared, liquids of different consistencies, herbs and minerals (vitamins and other supplements) (15). These were highlighted as facilitators by the large majority. Despite this study not aiming to verify which medicines the individuals who had CVA used, it is worth pointing out what is in the literature.

In the first instance, it is found the medicines that act efficiently in prevention, relapse and treatment of depression after CVA, contributing to improve the symptoms of this comorbidity and the decrease of mortality $(26,27)$. The antidepressant treatment can be performed with both noradrenergic and serotonergic drugs, with possible highest effectiveness of the first group (28 - 30). Other medicines, according to literature, will act to prevent harms and recurrence of CVA, such as antihypertensive, anticoagulant, thrombolytics medications, antiplatet (aspirin) and lipid-lowering medications $(26,31)$; these were perceived by individuals after CVA as being facilitators. Due to the importance that medications assume as facilitators, it is important to investigate, in the future, the relationship between these medications usage and other socio-economic and cultural aspects.

Interpersonal factors were presented as facilitators, by the interviewees, emphasized specifically in immediate family. According to ICF, immediate family is characterized by individuals related by birth, marriage or other relationships recognized by local culture (15). In this respect, the specialized literature points out that the interpersonal factors are facilitators to maintaining a healthy social life.

A favourable family environment promotes relief from pressures and assumes particular importance in providing instrumental and emotional support to the patient (32). Relatives, principally caregivers, act as facilitators to perform daily life activities; these activities cannot be performed without help from others, due to sequelae from CVA. Relatives are especially important as rehabilitation agents, as they afford security, "pep", affection and all the necessary support (33).

Relatives and caregivers also act as facilitators in food preparation, medications control, deambulation assistance, sanitization, bathroom assistance and in the performance of physical exercises, as well as accompaniment in medical appointments (34). They act as facilitators in the rehabilitation process, keeping in mind that this activity would be hard to be performed without the presence of these people. In a study conducted by Glass (35), the majority of 
patients who received considerable social support demonstrated continuous improvement of functional status after the $4^{\text {th }}$ and the $6^{\text {th }}$ weeks of recovery. However, people who had CVA and received from little to minimal social support demonstrated decrease in functional status between the $3^{\text {rd }}$ and the $6^{\text {th }}$ months (35). People who had mild CVA may be neglected by family due to underestimation of their need for support and, as a result, present higher risk of social isolation. In contrast, people with high levels of social support recover faster, and with greater extension, even individuals seriously damaged.

The recognition of health professionals as facilitators highlights the importance of these workers in the health-disease process in patients after CVA. According to ICF, health professionals are service providers which work in a health system context, such as physicians, nurses, physiotherapists, occupational therapists, speech therapists, audiologists, prosthetics and social assistants by medical field (15).

In a study conducted by O'Halloran, 2012, the physical presence of a health professional in a hospital unit acts as a facilitator to patients with difficulties in interpersonal communication as a result from CVA (22). This occurs when the professional seems to be willing to talk and offer information about the diagnosis and medical procedures, allowing greater participation/interaction with the patient or family members, in making health decisions.

Participation of health professionals in educational interventions, targeted at relatives and caregivers, can also be a facilitator. This participation is helpful by preparing both relatives and caregivers to face situations that will be imposed on the closest people to the ones who had CVA. It also provides stimulation for both the family and the individual, so they can be capable to act with disabilities and in a perspective which emphasizes the individual's possibilities. These professionals are able to divulge information about the illness, its consequences and therapeutic resources that possibly can be utilized. The action of a multi-professional team also brings other benefits. When they are well oriented, along with the person who had CVA, relatives and caregivers, knowing, for example, the right names of medications, dosage, time, side effects and the mainly drug interactions, it is possible to improve the quality of life of the individual, reduce the number of hospitalizations and encourage participation in social and leisure activities $(4,13,33)$.
The effective participation of health professionals, such as physiotherapists, nutritionists, psychologists, pharmacists, physicians, nurses, dentists, physical education teachers and social assistants, associated with the individual's family support, enables orientation and clarifies doubts about exercises, nutrition, leisure, medications, work and sex. Thereby, health professionals integrate the social support network of people with CVA sequelae. The family of these individuals assume the role of facilitators in prevention and/or treatment of chronic diseases (36).

Social support is defined as a support system, which enables assistance and encouragement for individuals with physical or emotional disabilities, so they can overcome this health condition. Social support also favors the execution of daily activities. Strategies that allow the care practice must focus on the individual as a whole; these promote and re-establish health, as well as physical and mental well-being. Included in this context are the different emotional, informative and instrumental resources, which patients receive through social relations, from peer and family to wide social relationships, such as groups and social network $(37,38)$.

Extended family must also be regarded as a facilitator in the rehabilitation process after CVA. ICF describes Extend family as individuals related by either family or marriage, or other relationships recognized by local culture, such as relatives, aunts, uncles, nephews and nieces (15). In addition, contact with friends, peers and neighbors is essential to facilitate social network support.

According to ICF, friends are individuals in close and long-term relationships characterized by mutual support and trust. Acquaintances, partners, neighbors and community members are individuals that maintain a relationship of familiarity at work, school, recreation, or in other life aspects. They typically share demographic characteristics such as age, gender, faith or ethnicity or other similar interests (15).

The existence of a social network, which supports relatives, friends and neighbors, helps the process of dealing with the disease, offering support to every family member and giving more autonomy to the CVA patient. It acts in decreasing stress, lifting self-esteem and helping the family to handle adversities. It is a facilitator because it enables and qualifies the family's fundamental responsibility (13).

After CVA, the presence of loved people, principally immediate and extended families help both in 
instrumental and emotional support $(32,39)$. These individuals stimulate the CVA patient to recover. Therefore, this support network also needs to be stimulated, since it becomes fundamental for rehabilitation and increasing the quality of life of these individuals. These people also needs elevated stimuli for their recovery; these stimulations can be visual, auditory, participatory, emotional or (any other stimuli which involve them, because contact with other people, participation in activities and healthy family environments act as facilitators in rehabilitation of CVA victims (39).

Regarding the factors related to physical structure, either public or private building construction and private residence, more than half of interviewees pointed it out as facilitating the execution of their daily activities. Walking impairment or difficulty resulting from CVA can cause social disadvantages to the individual, once it reflects directly on daily activities performance. Limitation of access to spaces constitutes limitation to the individuals' performance; it influences independence and the condition to assume previous roles of the disease $(40,41)$. Due to impairment, as a result of CVA, physical spaces must be adapted to individual's new reality; these physical spaces can facilitate transition of the individual to home, work, or community (16).

According to ICF, products and technologies used in projects, architecture, and public or private building construction represent products and technology that form internal and external spaces of planned environment projected and built by individuals, for public or private usage, including those adapted or specially planned. It also includes products and technology used in project, architecture and construction of exits, facilities and direction indicators (15). Physical geography is represented by characteristics of land and hydrography. Geographical characteristics include orography (topography, quality and expansion of the land and its types, including altitude) and hydrography (water extension, such as lakes, rivers and seas) (15). Interviewees considered physical geography of their homes and community surroundings where they live.

Products and technologies used in projects, architecture, and public or private building construction, when well structured, enable leisure and individuals' socialization, contributing to quality of life. However, the lack of infrastructure and proper maintenance by government, and even users, compromise accessibility in these environments, such as the lack of specific parking for people with disabilities or reduced mobility, poorly constructed stairs at buildings entrance and some theatres and auditoriums, which do not have specific areas for wheelchair users (16). Ramps with low or no inclination, adapted elevators, non-adapted bathrooms, lack of handrails, inappropriate entrances and exits, etc., sometimes can hamper or limit these spaces usage and impede social participation and circulation in the environment by individuals with physical restrictions, such as people with CVA sequelae.

According to Bins et al. (42), restrictions imposed by environment in public spaces can result in difficulties in perception of its information, due to sensory system limitations. Among them are included the question about orientation difficulties found in activities which need physical strength, motor coordination, precision or mobility; difficulties in treatment of received information or in communication due to cognitive system limitations. There are still the multiple restrictions, derived from association of more than one type of restriction (42).

Concerning the physical geography of the individual's home, it can be noticed that some factors become relevant and contribute for users to perceive and consider structures presented in the environment where they live as architectural barriers. In a research carried by Garanhani et al. (23), most of the houses visited presented stairs and irregular grounds, which can represent a major barrier to disabled people, such as those with deambulation, balance or visual problems and wheelchair and walker users (23).

On a study carried by Algurén et al. (43), half of the participants who were between the sixth week and third month after CVA described physical geography of their area as barriers, which impeded them to leave home due to this area to be mountainous, wooded and with frequently rises (43).

Association between immediate family and the variable marital status indicates the spouse's importance in the life of individuals after CVA. Degree of relatedness, affectivity and living in the same house are factors presented on people who are caregivers; they help these individuals in personal and social activities after CVA $(13,44)$. The presence of active sexual life, at least weekly, is seen a facilitator in the rehabilitation process after CVA (39). Significant gains related to immediate and delayed memory suggests that emotional support can improve the cognition in patients after CVA. 
Regarding products and technologies for personal consumption in daily life, such as assistive technologies, there was prevalence in the usage of these equipments in daily activities among elderly individuals comparing to young ones. Due to the increase in life expectancy in the last decades, especially in individuals who had suffered from any chronic disease, such as the cerebrovascular accident, we perceive the increasingly number of elderly individuals functionally disable and presenting weaken health, which need to use these technologies to ensure better performance in activities they perform, even with this disability (23).

Advancement of policy management for disabled people demonstrates the need for a better distribution and utilization of assistive technologies, because there is evidence of their efficacy in reduction of physical dysfunctions, facilitating functional performance and autonomy; the assistive technologies also prevent accidental falls, keep the balance and improve mobility in individuals after CVA $(24,45)$.

CVA, due to deficits in structure and function domains, causes limitations relative to individual's social life (46). Therefore, the usage of these assistive devices will act in order to decrease the physical impacts caused by CVA. These devices act as compensators due to function loss, by facilitating the interaction between function limitations and physical geography demand, promoting greater independence and quality of life (16).

Friends were significantly associated to variable gender; women identified friendship as a facilitator in after CVA period. The strengthen of friendship can improve life conditions due to impact on psychosocial aspect. According to Crooks et al. (47), friendships influence protecting cognitive health of elderly women, by reducing significantly the incidence of diseases that affect cognition (47). A study carried by Ertel et al. , affirms that women with well-established friendships present cognitive decline twice slower than those with little social integration (48). Maintenance and strengthen of friendship acts positively in elderly women's cognition.

Data from this study reinforce the need for greater attention to products and technologies for use in daily life by individuals diagnosed with CVA as they may contribute to the development of new skills and facilitate more autonomy. These devices enable effective communication, influence decision-making and generate positive feelings in disabled individuals, as well as open opportunities that enable interaction between this population and their caregivers (15).
The study suggests the need to investigate further the social representations of the medication for people in post-stroke, and finally, the study emphasizes the need to investigate the role of family, and other stakeholders as facilitators of greater social participation for this population.

The study also points to the challenge of rethinking individual and collective actions that may enable the transformation of public and private spaces for those who suffer the consequences of CVA.

\section{Acknowledgements}

This research was financed by Foundation of Support for Research of the State of Paraíba (FAPESQ process number 005/2009) and National Council for Scientific and Technological Development (CNPq) in partnership with Federal University of Paraíba (UFPB). Logistic support was given by Municipal Secretariat of Health of João Pessoa, Paraíba, Brazil.

\section{References}

1. Instituto Brasileiro de Geografia e Estatística (IBGE). Censo Demográfico: Resultados Preliminares da Amostra. 2011 [cited 2012 Aug 24]. Available from: http://www.ibge.gov.br/home/estatistica/populacao/ censo2010/resultados_preliminares_amostra/default resultados_preliminares_amostra.shtm.

2. Brasil, Ministério da Saúde. Secretaria de Atenção à Saúde. Política Nacional de Saúde da Pessoa Portadora de Deficiência. Ministério da Saúde: Brasília; 2007 [cited 2012 Apr 28]. Available from: http://bvsms. saude.gov.br/bvs/publicacoes/politica_nacional_ saude_pessoa_deficiencia.pdf

3. Organização Pan-Americana da Saúde (OPAS). Doenças crônico-degenerativas e obesidade: estratégia mundial sobre a alimentação saudável, atividade física e saúde. Brasília; 2003 [cited 2012 Aug 28]. Available from: http://www.opas.org.br/wp-content/ uploads/2015/09/d_cronic.pdf

4. Souza CB, Abreu RNDC, Brito EM, Moreira TMM, Silva LMMS, Vasconcelos SMM. O cuidado domiciliar de idosos acometidos por acidente vascular cerebral: cuidadores familiares. Rev enferm UERJ. 2009; 17(1): 41-5. 
5. Perlini NMOG, Faro ACM. Cuidar de pessoa incapacitada por acidente vascular cerebral no domicílio: o fazer do cuidador familiar. Rev Esc Enferm USP. 2005; 39(2): 154-63.

6. Veloso F, Reis LA, Azoubel R, Xavier TT, Argôlo SM. Um olhar sobre a assistência fisioterapêutica a portadores de Acidente Vascular Encefálico no município de Jequié-BA. Rev Saúde.com. 2007; 3(1): 55-63.

7. World Health Organization. Recommendations on stroke prevention, diagnosis, and therapy. Report of the WHO task force on stroke and other cerebrovascular disorders. Stroke. 1989; 20(10): 1407-31.

8. Stokes M. Neurologia para fisioterapeutas. In: Durward B, Baer G, Wade J. Acidente Vascular Cerebral. Colombia: Premier; 2000. p. 83-100.

9. Curioni C, Cunha CB, Veras RP, André C. The decline in mortality from circulatory diseases in Brazil. Rev Panam Salud Publica. 2009; 25(1): 9-15.

10. Brasil, Ministério da Saúde. Indicadores de morbidade/DATASUS. Brasília; 2009 [cited 2012 Apr 28]. Available from: http://www.datasus.gov.br.

11. Amaral FLJS, Quirino MAB, Nascimento JPS, Neves RF, Ribeiro KSQDS, Alves SB. Acessibilidade de pessoas com deficiência ou restrição permanente de mobilidade ao SUS. Ciênc Saúde Coletiva. 2012; 17(7): 1833-40.

12. Adams RD, Victor M, Ropper AH. Neurologia. In: Doenças vasculares cerebrais. Santiago do Chile: McGraw-Hill; 1998. p 513-75.

13. Brito ES, Rabinovich EP. Desarrumou Tudo! O Impacto do Acidente Vascular Encefálico na Família. Saude Soc. 2008; 17(2): 153-69.

14. Nordenfelt L. Action theory, disability and ICF. Disabil Rehabil. 2003; 25(18): 1075-9.

15. World Health Organization. International classification of functioning, disability and health. Lisboa: Direcção Geral da Saúde; 2004.

16. O' Sullivan SB, Schmitz TJ. Fisioterapia: Avaliação e Tratamento. São Paulo: Manole; 2010. p 437- 71.
17. Dahl, TH. International classification of functioning disability and Health. An introduction and discussion of its potencial impact on rehabilitation services and research. J Rehabil Med. 2002; 34(5): 201- 4.

18. Geyh S, Cieza A, Schouten J, Dickson H, Frommelt P, Omar Z, et al. ICF Core Sets For Stroke. J Rehabil Med. 2004; Jul (Suppl 44): 135- 41.

19. Almeida OP. Mini Exame do estado mental e o diagnóstico de demência no Brasil. Arq Neuro-Psiquiatr. 1998; 56(3B): 605-12.

20. Legg C, Young L, Bryer A. Training sixth-year medical students in obtaining case-history information from adults with aphasia. Aphasiology. 2005; 19(6) : 559-75.

21. Brennan A, Worrall L, McKenna K. The relationship between specific features of aphasia-friendly written material and comprehension of written material for people with aphasia: an exploratory study. Aphasiology. 2005; 19(8): 693-711.

22. O'Halloran R, Grohn B, Worrall L. Environmental Factors That Influence Communication for Patients With a Communication Disability in Acute Hospital Stroke Units: A Qualitative Metasynthesis. Arch Phys Med Rehabil. 2012; 93(Suppl 1): 77-85.

23. Garanhani MR, Alves JF, Fugisawa DS, Garanhani ML. Adaptação da pessoa após acidente vascular encefálico e seu cuidador: ambiente domiciliar, cadeira de rodas e de banho. Acta Fisiatr. 2010; 17(4): 164- 8.

24. Polese JC, Nascimento LR, Faria CDCM, Laurentino GEC, Paula FR, Ada L, et al. Percepção de hemiplégicos crônicos sobre o uso de dispositivos auxiliares na marcha. Rev. Panam. Salud Publica. 2011; 30(3): 204- 8.

25. Andrade VS, Pereira LSM. Influência da tecnologia assistiva no desempenho funcional e na qualidade de vida de idosos comunitários frágeis: uma revisão bibliográfica. Rev Bras Geriatr Gerontol. 2009; 12(1): 113- 22.

26. Gitlin LN, Luborsky MR, Schemm RL. Emerging Concerns of Older Stroke Patients About Assistive Device Use. Gerontologist. 1998; 38(2): 169- 80.

27. Teng CT, Humes EC, Demetrio FN. Depressão e comorbidades clínicas. Rev Psiq Clín. 2005; 32(3): 149- 59. 
28. Ribeiro DS, Filho EAC, Losapio MF, Sena EP. Terapia medicamentosa na depressão pós-Acidente Vascular Encefálico. J Bras Psiquiatr. 2009; 58(2): 135- 42.

29. Robinson RG. Poststroke Depression: Prevalence, Diagnosis, Treatment, and Disease Progression. Biol Psychiatr. 2003; 54(3): 376- 87.

30. Wiart L, Petit H, Joseph PA, Mazaux JM, Barat M. Fluoxetine in Early Post-Stroke Depression: a Double-Blind Placebo- Controlled Study. Stroke. 2000; 31(8): 1829-32.

31. Fonseca AC, Henriques I, Ferro JM. Recomendações para o Tratamento do AVC Isquêmico e do Acidente Isquêmico Transitório. Sinapse 2008; 8(1): 5-67.

32. Cancela DMG. O acidente vascular cerebral - classificação, principais consequências e reabilitação [Internet]. Psicologia.pt; 2008 [cited 2012 Aug 15]. Avaiable from: http://www.psicologia.pt/artigos/ textos/TL0095.pdf.

33. Tsouna-Hadjis E, Vemmos KN, Zakopoulos N, Stamatelopoulos S. First-Stroke Recovery Process: The Role of Family Social Support. Arch Phys Med Rehabil. 2000; 81(1): 881-7.

34. Rodrigues LS, Alencar AMPG, Rocha EG. Paciente com Acidente Vascular Encefálico e a rede de apoio familiar. Rev Bras Enferm. 2009; 62(2 ): 272-7.

35. Glass TA, Matchar DB, Belyea M, Feussner JR. Impact of social support on outcome in first stroke. Stroke. 1993; 24(1): 64-70.

36. Vianna LG, Vianna C, Bezerra AJC. Relação MédicoPaciente idoso: desafios e perspectivas. Rev Bras Educ Med. 2010; 34(1): 150- 9.

37. Landim FLP, Araújo AF, Ximenes LB, Varela ZMV. Comunidade mutirante: características familiares e suas redes de suporte social. Rev Bras Promoç Saúde. 2004; 17(4): 177-86.

38. Lacerda A. Apoio social e a concepção do sujeito na sua integração entre corpo-mente: uma articulação de conceitos no campo da saúde pública [Dissertação]. Rio de Janeiro: Fundação Oswaldo Cruz; 2002. 94p. [cited 2012 Aug 17] . Avaiable from: http://arca.icict. fiocruz.br/handle/icict/5089.

39. Glymour MM, Weuve J, Fay ME, Glass T, Berkman LF. Social Ties and Cognitive Recovery after Stroke: Does Social Integration Promote Cognitive Resilience? Neuroepidemiology. 2008; 31(1): 10-20.
40. Perry J, Garrett M, Gronley JK, Mulroy SJ. Classification of walking handicap in the stroke population. Stroke. 1995; 26(6) : 982- 9.

41. Tennant A, Geddee JM, Fear J, Chamberlain MA. Outcome following stroke. Disabil Rehabil. 1997; 19(7) : 278-84.

42. Ely VHM, Souza JC, Dorneles VG, Koelzer MP, Wan-Dall Junior OA. Acessibilidade e inclusão em espaços livres públicos. In: Anais do ENTAC - XI Encontro Nacional de Tecnologia do Ambiente Construído, 2006; Florianópolis. p. 2752- 61.

43. Algurén B, Lundgren-Nilsson A, Sunnerhagen KS. Facilitators and barriers of stroke survivors in the early poststroke phase. Disabil Rehabil. 2009; 31(19): 1584-91.

44. Karsch UM. Idosos dependentes: famílias e cuidadores. Cad Saúde Pública. 2003; 19(3): 861- 6.

45. Mann WC, Llanes C, Justiss MD, Tomita M. Frail older adults' self-report of their most important assistive device. OTJR. 2004; 24(1): 4-12.

46. Salter K, Jutai JW, Teasell R, Foley NC, Bitensky J, Bayley M. Issues for selection of outcome measures in stroke rehabilitation: ICF activity. Disabil Rehabil. 2005; 27(6): 315- 40.

47. Crooks VC, Lubben J, Petitti DB, Little D, Chiu V. Social network, cognitive function, and dementia incidence among elderly women. Am J Public Health. 2008; 98(7): 1221- 7.

48. Ertel KA, Glymour MM, Berkman LF. Effects of social integration on preserving memory function in a nationally representative U.S. elderly population. Am J Public Health. 2008; 98(7): 1215- 20.

Received: 08/26/2014

Recebido: 26/08/2014

Approved: 08/14/2015

Aprovado: 14/08/2015 
